\title{
PRODUCTION PERFORMANCE OF SMALL RUMINANTS FED PRUNING FRUITS TREES BY PRODUCTS. 2- EFFECT OF TREATED PRUNING PEACH TREES BY-PRODUCTS ON GROWING SHEEP.
}

Khir, A. A.; A. A. Mahrous; Y. L. Phillip and Safa N. Abdel-Azeem. Animal Production Research Institute, Agricultural Research Center, Dokki, Giza, Egypt.

\begin{abstract}
This experiment was conducted to study the effect of chemical and biological treatments of pruning peach trees by-products (PTBP) on chemical composition, degradability, cell wall constituents, digestibility and nutritive value and its feeding effect on productive performance of growing sheep. Thirty Ossimi lambs with average body weight $18.00 \pm 0.20 \mathrm{~kg}$ and 4 months old were used in this study for 120 days. Lambs were distributed into five similar groups (6 lambs each) and randomly assigned to five experimental rations. The five respective rations composed of concentrate feed mixture (CFM) + roughage (PTBP), the control ration (R1) contained untreated PTBP; (R2) treated PTBP withTrichoderma reesei; (R3) treated PTBP with Trichoderma viride;(R4) treated PTBP with Trichoderma reesei + Trichoderma viride and (R5) 3\% urea treated PTBP. The DM, OM and CP disappearance and effective degradability (ED) va lues were in situ determined. The digestibility and nutritive values of experimental rations were determined using fifteen adult Ossimi rams. Rumen liquor and blood samples were collected at the end of collection period. The results showed that fractions of DM $(a \& b)$ and $(E D)$ were significantly $(P<0.05)$ increased with treated PTBP either with urea or fungi compared to control (untreated PTBP). The highest degradable values of $\mathrm{DM}, \mathrm{OM}$ and $\mathrm{CP}$ were observed with R4. Nutrient digestibility and feeding values (TDN and $D C P)$ were higher $(P<0.05)$ for rations containing treated PTBP than control. The highest values of TDN and DCP were observed for R4. Digestibility of cell wall constituents (NDF, ADF, cellulose and hemicellulose) were improved by treatments. Concentrations of rumen parameters $\left(\mathrm{NH}_{3}-\mathrm{N}\right.$ and TVFA's) were significantly increased by treatments. However, no significant differences were found in blood constituents (total protein, albumin, globulin, GOT, GPT and urea) among the different experimental groups. Blood constituents were generally normal in all experimental groups. Growth performance with respect to total body weight gain and average daily gain (ADG) were improved by biological treatments. The same trend was observed for feed conversion and economic efficiency and the best values were recoded with $\mathrm{R} 4$. It was concluded that inclusion of treated PTBP to rations of growing Ossimi lambs could improve their performance especially treatment of PTBP with fungi.

Keywords: Peach trees by product, biological treatments, fungus, digestibility, blood and rumen parameters, urea, degradation kinetics, sheep, growth.
\end{abstract}

\section{INTRODUCTION}

In Egypt, there is a wide gap between the available feedstuffs and farm animal requirements. Part of these needs can be covered by agricultural residues which include cereals crops and leguminous hays, cotton field's residues, vegetable crops residues, and waste products of pruning trees. The primary factors limiting the utilization of crop residues are their low digestibility, low protein content and low palatability. The low digestibility is 
attributed to high cellulose content (30-40\%), hemicellulose (25-35\%) and lignin (10-15\%) in the dry matter (Theander and Aman, 1984). Živković et al. (2013) and Bilandzija et al. (2012) reported that peach trees are important sources of pruning residues. They added that the amount of by-products after pruning remains in peach was $6.88-7.23 \mathrm{~kg}$ per tree. Taking into account the planting distance (number of tree per hectare) the amount of pruning by product of peach was 2.87-3.37 ton per hectare (approximately 1.17-1.36 ton per acre). In Egypt, peach are cultivated in an area of 67.7 thousand feddans (Egyptian Ministry of Agriculture, 2012) and produce considerable quantities of by-products. Most of these residues are burned or wasted, and hence lead to environmental pollution and consequently health hazards.

The waste agricultural residues mostly consist of poly-saccharides which are poorly digested by ruminants due to the presence of lignin which is recalcitrant to microbial degradation. Lignin also constitutes a physical barrier to the extraction and utilization of other components. The physical barrier of lignin can be broken either by physical, chemical or biological treatments (Belewu and Popoola, 2007).The chemical treatments, which has been used to improve palatability and digestibility of nutrients in crop residues include' urea treatment that was reported earlier (Hart and Wanapat, 1992; Khan et al., 1999 and Dass et al., 2000). This treatment also provides non-protein nitrogen (NPN) to ruminants diets (Jakson, 1977).Biological treatment is used for increasing the nutritional value of many by-products, because they have significant concentrations of simple carbohydrates, such as mono-and disaccharides. For these reasons, the microbial conversion of these wastes can improve their nutritional value and transforming them into animal feed with high quality (Villas-Boas et al., 2002). Most fungi are capable of degrading various varieties of substrates (Sancholle and Losel, 1995) and their role in the nutrition of animal (Belewu and Belewu, 2005 and Belewu, 2006).Moreover, Akinfemi and Ladipo (2013) showed that fungal treatment of sawdust enhances its nutrient contents and in vitro digestibility. The biological and urea treatments of grape trees by-products improved nutrients digestibility and nutritive values (under publication). Fungus treatments can be successfully used to enrich cotton stalks and improve the nutritive value (Deraz and Ismail 2001 and Mahrous, 2005)

The objectives of this study were to investigate the effects of fungal or urea treatments of pruning peach trees by-products on chemical composition, digestibility, nutritive value and growth performance of Ossimi lambs and its economic efficiency.

\section{MATERIALS AND METHODS}

The experimental work of this study was carried out at Seds Experimental Station, Animal Production Research Institute, Agriculture Research Center. Thirty Ossimi lambs at four months of age with an average live body weight of $18 \pm 0.2 \mathrm{~kg}$ were randomly assigned to five groups according to live body weight (6 lambs for each). Animals in all groups were fed rations consisting of concentrate feed mixture (CFU) to cover their maintenance requirements according to NRC (1985) recommendations while, 
pruning trees by- products (PTBP) were offered ad lib. The animals were fed the five respective rations in two meals /day ( $8 \mathrm{am}$ and $3 \mathrm{pm})$.Trichoderma reesei ( $T$. reesei) and Trichoderma viride ( $T$. viride) were obtained from the Microbial Chemistry Department, National Research Center, and Dokki, Egypt. The microorganisms were preserved on Potato Dextrose Agar (PDA) medium at $25^{\circ} \mathrm{C}$ until used.

The PTBP was chopped into $3-5 \mathrm{~cm}$ then packed till using. Fifty grams of residue under investigation were weighed, packed in heat resistant bags $(10 \times 20 \mathrm{~cm})$ and sterilized by autoclaving at $121{ }^{\circ} \mathrm{C}$ for 30 minutes. Spore suspension of $T$. reesei and $T$. viride were prepared and used to inoculate a sterilized liquid medium containing $(\mathrm{g} / \mathrm{L}) 4 \%$ molasses, $0.4 \%$ urea, $0.2 \% \mathrm{KH}_{2}$ $\mathrm{PO}_{4}$ and $0.03 \% \mathrm{MgSO}_{4} .7 \mathrm{H}_{2} \mathrm{O}$ and incubated for 7 days. Urea-treated PTBP was prepared by using $3 \mathrm{~kg}$ urea of fertilizer grade $(46 \% \mathrm{~N})$ plus 50 liter water sprayed onto $100 \mathrm{~kg}$ of PTBP and then covered up for 21 days before directly feeding to the animals. The fungal treated PTBP was moistened to $65-$ $70 \%$ and put specific fungal spawn and left for three weeks. The untreated and the treated PTBP were analyzed for (DM), crude protein (CP), ether extract (EE), crude fiber (CF) and ash content according to the A.O.A.C (1995). Neutral detergent fiber (NDF), acid detergent fiber (ADF) and acid detergent lignin (ADL) were determined by the methods of Van Soest (1982).

Three ruminally canulated Ossimi rams were used for the in situ trials. Nylon bags technique (Mehrez and Ørskov, 1977) was used to determine DM, OM and CP disappearance of roughage. Two polyester bags $(7 \times 15 \mathrm{~cm})$ with pore size of $45 \mu \mathrm{m}$ were used for each incubation time; approximately $5 \mathrm{~g}$ of air dried roughage (ground to $2 \mathrm{~mm}$ ) were placed in each bag. Bags were incubated in rumen of each sheep and withdrawn after $3,6,12,24,72$, and $96 \mathrm{~h}$. After the bags were withdrawn from the rumen, they were rinsed in tap water until the water became clear, then they were squeezed gently. Microorganisms attached to the residual samples were eliminated by freezing at $-20^{\circ} \mathrm{C}$ (Kamel et al. 1995). Zero time washing losses $(A)$ were determined by washing 2 bags in running water for $15 \mathrm{~min}$. The degradation kinetics of DM, OM and CP were estimated (in each bag) by fitting the disappearance values to the equation $\mathrm{P}=\mathrm{a}+\mathrm{b}\left(1-\mathrm{e}^{-\mathrm{ct}}\right)$ as proposed by Ørskov and MacDoland (1979), where $P$ represents the disappearance after time $(t)$. Least squares estimated soluble fractions are defined as the rapidly degraded fraction (a), slowly degraded fraction (b) and the rate of degradation (c), respectively. The effective degradability (ED) for the tested were estimated from the equation cited by McDonald (1981), ED=a + bc (c + $\mathrm{K}$ ), where $\mathrm{k}$ is the out flow rate assumed to be $0.03 / \mathrm{hr}$ (Ørskov and Ryle, 1990).

A digestibility trial was conducted using fifteen adult Ossimi rams and divided into five similar groups ( 3 animals for each) averaged $55 \mathrm{~kg}$ and 3 years old. Animals were housed in individual metabolic cages for 21 days (14 days as a preliminary period followed by 7 days as collection period) to determine the digestibility coefficients and nutritive values of the five tested rations. The five groups titled R1: untreated PTBP (control); R2: PTBP treated with T. reesei; R3: PTBP treated with T. viride; R4: PTBP treated with 
(T. reesei $+T$. viride) and R5: PTBP treated with $3 \%$ urea. All groups were fed PTBP untreated or treated ad. Lib. Feces were collected quantitatively every day and $10 \%$ daily sample was taken and sprayed with $10 \%$ sulfuric acid and dried during the collection period. At the end of the collection period, feces samples for each ram were ground mixed well and kept in the refrigerator till its chemical analysis. Rumen liquor samples were taken from each animal at the end of collection period by stomach tube at o, 3 and $6 \mathrm{hrs}$. post-feeding. The ruminal $\mathrm{pH}$ values were measured immediately by $\mathrm{pH}$ meter (Orion Research, model 201/digital pH meter). Ammonia nitrogen $\left(\mathrm{NH}_{3}-\mathrm{N}\right)$ concentration was measured according to Conway and O'Mally (1957). Total VFA's concentration was determined by the steam distillation method according to Abou-Akkada and Osman (1967). Blood samples were collected from the jugular vein at $3 \mathrm{hrs}$.post-feeding and centrifuged for 20 min. at 3000 r.p.m. The supernatant was frozen and stored at $-20^{\circ} \mathrm{C}$ for subsequent analysis. Plasma total protein was determined according to Armstrong and Carr (1964); albumin according to (Doumas et al., 1971); GOT and GPT according to (Reitman and Frankel, 1957); and urea according to (Siest et al., 1981).

Collected data were subjected to statistical analysis using one-wayanalysis of variance according to Snedecor and Cochran (1980) using the following model:

$$
\mathbf{Y}_{\mathrm{ij}}=\mu+\mathrm{T}_{\mathrm{i}}+\mathbf{e}_{\mathrm{ij}}
$$

Where: $Y_{i j}$ is the parameter under analysis, $\mu$ is the overall mean, $T_{i}$ is the effect due to treatment and $e_{i j}$ is the experimental error. The general linear model of SAS (2001) program was used in processing measured parameters. The difference between means was statistically measured for significance at $(P<0.05)$ according to Duncan's test (1955).

\section{RESULTS AND DISCUSSION}

\section{Chemical composition:}

Table (1) shows the effect of chemical and biological treatments on chemical composition and cell wall constituents of pruning peach trees by products (PTBP). The present data indicated that the values of DM, OM, CF and NFE were decreased in treated PTBP; however, CP was increased from $3.34 \%$ for untreated PTBP to $5.8,6.41,7.32$ and $5.20 \%$ for T.reesei (T2), T.viride (T3), T.reesei+ T.viride (T4) and urea (T5) treatments, respectively. The same trend was observed with ash content since it increased either with urea or fungal treated PTBP. Results are in agreement with those obtained by Mahrous et al. (2010\&2011) and El-Ashry et al. (2002) who reported that in fungal treated residues (sugarcane bagasse, wheat straw, cotton stalks, pinnae and mid ripe of date palms), CP and ash contents were increased but DM, OM, CF and NFE contents were decreased. Also, Fayed et al. (2009) reported that urea or fungal treatment of olive leaves led to decrease CF content; meanwhile, CP and ash contents were increased in comparison with those for untreated olive leaves. 
Table (1): Chemical composition and fiber fractions of untreated and treated pruning peach trees by-products and CFM (\% on DM basis).

\begin{tabular}{|c|c|c|c|c|c|c|}
\hline \multirow{2}{*}{ Item } & \multicolumn{5}{|c|}{ Treatments } & \multirow{2}{*}{ CFM } \\
\hline & T1 & T2 & T3 & T4 & T5 & \\
\hline \multicolumn{7}{|c|}{ Chemical composition: } \\
\hline $\mathrm{DM}$ & 91.56 & 89.30 & 88.41 & 87.60 & 90.20 & 88.7 \\
\hline OM & 90.64 & 85.80 & 86.48 & 85.38 & 87.21 & 92.82 \\
\hline $\mathrm{CP}$ & 3.34 & 5.80 & 6.41 & 7.32 & 5.20 & 14.16 \\
\hline CF & 53.53 & 48.37 & 47.20 & 46.32 & 49.11 & 11.05 \\
\hline EE & 0.67 & 1.10 & 1.80 & 1.18 & 0.83 & 2.3 \\
\hline NFE & 33.10 & 30.53 & 31.01 & 30.56 & 32.07 & 65.31 \\
\hline Ash & 9.30 & 14.20 & 13.58 & 14.62 & 12.79 & 7.18 \\
\hline \multicolumn{7}{|c|}{ Cell wall constituents: } \\
\hline NDF & 81.65 & 77.32 & 77.80 & 74.20 & 78.30 & 27.79 \\
\hline ADF & 67.72 & 63.22 & 62.94 & 59.31 & 64.15 & 8.86 \\
\hline ADL & 37.84 & 28.30 & 28.10 & 26.05 & 30.46 & 2.89 \\
\hline Cellulose & 29.88 & 34.92 & 34.84 & 33.26 & 33.69 & 5.88 \\
\hline Hemicelluloses & 13.93 & 14.10 & 1.86 & 14.89 & 14.15 & 18.89 \\
\hline
\end{tabular}

Chandra et al.(1991) claimed that the content of OM decreased as a reflection of CF decreasing which was utilized by fungi ( $T$. viride, $A$. niger and mixed fungi) while, the increase in ash content was inversely related to the loss OM content of treated paddy straw. Salman et al. (2011) reported that $\mathrm{CP}$ content increased in chemical (urea) or biological (fungi and bacteria) treated sugarcane bagasse. This effect may be mainly due to nitrogen content of added urea in chemical treatments or microbial protein in biological treatment as a result of growing fungi. The decrease in CF content of the experimental roughage could be resultant of the enzymes secreted by bacteria or fungi in biological treatments (Gado et al., 2007). However, Abd El-Ghani et al. (1999) indicated that CF content was decreased by urea treatment which was mainly due to the liberation of cellulose from its bonds with lignin (delignification) which increased their solubility. Chandra et al. (1991) mentioned that the increase of ash in chemical or biological treatments reflected the decrease in CF and NFE contents.

The NDF, ADF and ADL decreased after the treatment of PTBP by either chemical or biological treatments. The NDF values were decreased by about $5.30,4.72,9.12$ and $1.25 \%$ and the corresponding values of ADF were $6.65,7.06,12.42$ and $5.27 \%$ for, T2, T3, T4 and T5 respectively. While the values of cellulose and hemicelluloses were increased by treatments. These findings agree with those found by Akinfemi and Ladipo (2013) who observed reductions in NDF, ADF and ADL values as a result of fungal treatment of sawdust. Fungal treatment depleted the hemicellulose fraction compared with control, whereas, the cellulose fraction was significantly increased. Also, 
Mahrous et al. (2010\&2011) reported that the biological treatment (T. viride) of sugarcane bagasse resulted in decreasing NDF and ADF, while cellulose and hemicellulose were increased. Fayed et al. (2009) showed that urea treatment and biological treatment decreased all fiber fractions of pruning olive trees by-products. However, Verma et al. (2006) found that urea treatment of wheat straw substantially enhanced the content of ADF and cellulose, while, the content of hemicellulose and NDF were decreased. The incubation of sawdust with fungus reduced the crude fiber content and fiber fraction probably due to enzymatic action of the fungus on fiber (Belewu, and Popoola, 2007). Fungi cultivation decreased the amount of NDF and ADF in wheat straw and barley straw, while, ADL content did not differ by treating with fungi (Nasehi et al., 2014).

Degradation kinetics:

Degradability kinetics of DM, OM and CP for peach trees by products in the rumen of sheep are presented in Table (2).

Table (2): Degradation kinetics of DM, OM and CP for un-treated and treated peach trees by-products in rumen of sheep.

\begin{tabular}{|c|c|c|c|c|c|c|}
\hline & T1 & T2 & T3 & T4 & T5 & \pm SE \\
\hline \multicolumn{7}{|c|}{ DM } \\
\hline$a$ & $17.81^{\mathrm{d}}$ & $20.96^{b}$ & $21.26^{b}$ & $22.71^{a}$ & $19.30^{C}$ & 0.180 \\
\hline $\mathrm{b}$ & $31.43^{\mathrm{d}}$ & $36.61^{b}$ & $37.72^{a}$ & $37.27^{a}$ & $32.35^{\mathrm{C}}$ & 0.312 \\
\hline C & 0.050 & 0.052 & 0.050 & 0.052 & 0.053 & 0.002 \\
\hline$\mu$ & $50.16^{a}$ & $42.88^{\mathrm{C}}$ & $41.02^{\mathrm{d}}$ & $40.01^{\mathrm{e}}$ & $48.35^{b}$ & 0.326 \\
\hline \multirow[t]{2}{*}{ ED } & $40.27^{\mathrm{e}}$ & $46.91^{\mathrm{C}}$ & $47.65^{b}$ & $49.35^{a}$ & $42.82^{\mathrm{d}}$ & 0.146 \\
\hline & \multicolumn{6}{|c|}{ OM } \\
\hline$a$ & $13.83^{\mathrm{d}}$ & $18.75^{b}$ & $18.97^{b}$ & $20.02^{\mathrm{a}}$ & $15.69^{c}$ & 0.219 \\
\hline$b$ & $32.83^{d}$ & $37.66^{a}$ & $38.09^{a}$ & $36.77^{b}$ & $35.12^{C}$ & 0.261 \\
\hline C & $0.047^{\mathrm{C}}$ & $0.047^{c}$ & $0.050^{\mathrm{bC}}$ & $0.058^{a}$ & $0.053^{\mathrm{ab}}$ & 0.002 \\
\hline$\mu$ & $53.34^{a}$ & $43.60^{\circ}$ & $42.93^{\mathrm{C}}$ & $43.21^{\mathrm{C}}$ & $49.19^{b}$ & 0.258 \\
\hline \multirow[t]{2}{*}{ ED } & $36.74^{\mathrm{e}}$ & $44.98^{\mathrm{C}}$ & $46.25^{b}$ & $47.39^{a}$ & $40.84^{\mathrm{d}}$ & 0.109 \\
\hline & \multicolumn{6}{|c|}{ CP } \\
\hline$a$ & $9.24^{\mathrm{e}}$ & $14.06^{\mathrm{D}}$ & $12.69^{c}$ & $14.56^{a}$ & $11.55^{\mathrm{a}}$ & 0.168 \\
\hline$b$ & $33.83^{d}$ & $36.58^{a}$ & $35.20^{\mathrm{bc}}$ & $35.89^{\mathrm{ab}}$ & $34.52^{\mathrm{cd}}$ & 0.360 \\
\hline$c$ & 0.050 & 0.052 & 0.052 & 0.050 & 0.050 & 0.001 \\
\hline$\mu$ & $56.94^{\mathrm{a}}$ & $49.37^{d}$ & $52.11^{\mathrm{C}}$ & $49.52^{\mathrm{d}}$ & $53.92^{D}$ & 0.255 \\
\hline ED & $33.21^{\mathrm{d}}$ & $38.06^{b}$ & $40.29^{a}$ & $40.11^{a}$ & $36.10^{C}$ & 0.109 \\
\hline
\end{tabular}

${ }^{a, b, c, d}$ and ${ }^{e}$ Means in the same row with different superscript letters are significantly $(P<0.05)$ different.

a: soluble fraction(\%); b: potentially degradable fraction(\%); c: rate of nutrient degradation $\left(\% h^{-1}\right) ; \mu$ : un-degradable fraction $[\mu=100-(a+b)] ; E D:$ effective degradability $=a+[b c / c+k]$, where $k$ is the out flow rate assumed to be $0.03 / \mathrm{hr}$.T1: un-treated PTBP;T2: PTBP treated with T. reesei; T3: PTBP treated with T. viride; T4: PTBP treated with T. reesei +T. viride; and T5: PTBP treated with urea.

The soluble fractions (a) and (b) values of $\mathrm{DM}$, OM and CP were significantly $(P<0.05)$ higher either for urea or fungal treated PTBP than that for un-treated PTBP. The highest values were observed for fungal treatments followed by urea treatment. There were no significant $(P<0.05)$ differences of (c) degradable values among all groups for DM and CP. While, the 
degradation rate $(c)$ of OM significantly $(P<0.05)$ increased when PTBP was treated with the two fungi (T4) or urea treatment. The highest un-degradable fraction $(\mathrm{u})$ values of $\mathrm{DM}, \mathrm{OM}$ and $\mathrm{CP}$ were noticed with T1 (untreated PTBP) followed by urea then fungal treated PTBP. The effective degradability (ED) values of $D M, O M$ and $C P$ were significantly $(P<0.05)$ increased with all treatments and the highest values were observed with T4 compared with the control (T1). Similar results have been reported by Shoukry et al. (1985) who reported that in vitro and in situ DM disappearance increased for sugarcane bagasse treated with T.viride. IN the same trend, DM and OM degradability were significantly $(P<0.05)$ increased for either rice straw or corn stalks treated with T.viride compared to those for untreated one (Abdel-Azim et al., 2011). Also, Gado (1999) and Abo-Eid et al. (2007) reported that in vitro and in situ trials $\mathrm{DM}$ and $\mathrm{OM}$ degradability were increased $(\mathrm{P}<0.05)$ for all tested crop residues (rice straw, bagasse, wheat straw, cotton stalks and corn stalks) treated with T. reesei compared to the un-treated ones. Generally, urea and fungal treatments increased degradability of PTBP. Similar results have been reported by Bassuny et al. (2003a) who reported that the values of in vitro digestibility were improved by fungal, chemical and biochemical treatments for some crop residues (corn cobs and sugarcane bagasse) compared with control values, the best efficiency was obtained by urea plus fungi followed by fungi then urea treatment. Also, Salman et al. (2011) found that the best in vitro OM digestibility values were observed with either fungal or bacterial treated bagasse followed by that for $3 \%$ urea treated bagasse.

Digestibility coefficients and feeding value:

Digestion coefficients and feeding values of experimental rations are presented in Table (3). Data revealed that urea and fungal treatments had significantly higher $(P<0.05)$ digestibility values for all nutrients; however; the highest value was achieved with fungal treated PTBP especially with R4. Digestibility of cell wall constituents (NDF, ADF, cellulose and hemicellulose) were increased by urea and fungal treatments and the best value was observed for R4. These results are in agreement with those obtained by Abdel-Malik et al. (2003) who reported that digestibility of DM, OM, CP, CF, NFE, NDF, ADF, cellulose and hemicellulose were significantly increased $(P<0.05)$ for banana by products treated with either chemical (urea or acid plus urea) or biological treatments (bacteria, fungi, or bacteria plus fungi) in comparison with those for untreated one. Also, Deraz (1996); Zewil (2005); El-Kady et al. (2006) and Allam et al. (2006b) reported that animals fed biologically treated roughages were almost most efficient followed by those fed chemically treated roughages. The digestibility of CF, NDF and cellulose were higher $(P<0.05)$ with urea treated banana wastes than the control (untreated), but it was lower than biologically treated roughage (Hassan et al., 2005). The fungi treatments had the effect of loosening lingocellulitic bond and solubilize some of hemicellulose content (Hammouda, 1996; El-Ashry et al., 1997 and Fouad et al., 1998). Silva and Ørskov (1998) reported that urea treatment increased the nutritional value of wheat straw by making more digestible cellulose and hemicellulose available. This creates favorable conditions in the rumen for developments of the cellulolytic bacteria which 
specialized in degrading the cell wall. Moreover, urea treatment increased the degradable fraction of straw, as well as the rate of degradation (Nandra et al., 1983 and Ibrahim et al., 1989).

Table (3): Effect of biological treatments on apparent digestibility and feeding values of experimental rations.

\begin{tabular}{|c|c|c|c|c|c|c|}
\hline \multirow{2}{*}{ Item } & \multicolumn{5}{|c|}{ Experimental rations } & \multirow{2}{*}{ \pm SE } \\
\hline & R1 & R2 & R3 & R4 & R5 & \\
\hline \multicolumn{6}{|c|}{ Digestibility, \%: } & \\
\hline DM & $52.45^{\mathrm{d}}$ & $58.28^{\mathrm{b}}$ & $60.01^{a}$ & $61.46^{\mathrm{a}}$ & $54.90^{\mathrm{C}}$ & 0.501 \\
\hline OM & $52.22^{\mathrm{d}}$ & $60.41^{\mathrm{D}}$ & $61.76^{b}$ & $64.06^{\mathrm{a}}$ & $56.45^{\mathrm{C}}$ & 0.420 \\
\hline $\mathrm{CP}$ & $52.21^{\mathrm{C}}$ & $62.25^{\mathrm{a}}$ & $63.26^{\mathrm{a}}$ & $64.33^{\mathrm{a}}$ & $57.23^{\mathrm{D}}$ & 0.760 \\
\hline $\mathrm{CF}$ & $47.97^{\mathrm{C}}$ & $53.31^{b}$ & $55.83^{b}$ & $61.80^{\mathrm{a}}$ & $53.91^{\mathrm{b}}$ & 1.641 \\
\hline $\mathrm{EE}$ & $72.44^{\mathrm{D}}$ & $76.15^{\text {ab }}$ & $77.26^{\text {ab }}$ & $82.16^{a}$ & $70.44^{\mathrm{D}}$ & 2.180 \\
\hline NFE & $53.41^{\mathrm{c}}$ & $63.11^{\mathrm{a}}$ & $63.46^{\mathrm{a}}$ & $64.56^{\mathrm{a}}$ & $56.70^{\mathrm{b}}$ & 0.580 \\
\hline \multicolumn{7}{|c|}{ Cell wall constituents, $\%$} \\
\hline NDF & $45.15^{\mathrm{d}}$ & $53.51^{\mathrm{DC}}$ & $55.59^{\circ}$ & $58.52^{a}$ & $52.51^{\mathrm{C}}$ & 0.075 \\
\hline ADF & $34.20^{\mathrm{d}}$ & $41.67^{D}$ & $41.67^{b}$ & $43.18^{\mathrm{a}}$ & $38.81^{\mathrm{C}}$ & 0.448 \\
\hline ADL & 20.30 & 21.32 & 20.58 & 21.22 & 21.11 & 0.662 \\
\hline Cellulose & $48.61^{\mathrm{C}}$ & $55.96^{\mathrm{a}}$ & $56.74^{\mathrm{a}}$ & $57.86^{\mathrm{a}}$ & $52.36^{\mathrm{b}}$ & 0.799 \\
\hline Hemicellulose & $62.90^{C}$ & $76.08^{\mathrm{a}}$ & $76.28^{a}$ & $78.18^{\mathrm{a}}$ & $70.88^{D}$ & 1.055 \\
\hline \multicolumn{7}{|c|}{ Feeding value, $\%$} \\
\hline TDN & $49.30^{\mathrm{e}}$ & $56.58^{\mathrm{C}}$ & $58.05^{\mathrm{b}}$ & $60.35^{\mathrm{a}}$ & $52.26^{\mathrm{d}}$ & 0.361 \\
\hline $\mathrm{DCP}$ & $5.54^{\mathrm{d}}$ & $6.81^{\mathrm{C}}$ & $7.30^{\mathrm{b}}$ & $7.89^{\mathrm{a}}$ & $6.73^{\mathrm{C}}$ & 0.075 \\
\hline
\end{tabular}

Feeding values (TDN and DCP) of experimental rations that contained PTBP treated with urea or fungi had higher values $(P<0.05)$ than untreated PTBP (R1). However, rations contained fungal treated PTBP had significantly higher values compared with urea treatment ration especially; R4 which recorded the highest values among all rations (Table 3 ). These results revealed that fungal treatment was more effective for improving digestibility and feeding value of PTBP than urea treatment. Similar results were obtained by Salman et al. (2011) who reported that TDN and DCP of bagasse were improved by different treatments with the superiority of fungi or biochemical treatments compared with urea treatment. This improvement of feeding values for urea or biologically treated rations may be due to the improvement of most nutrient digestibility of treated rations. While the increase of DCP by treatment may be due to the increase $\mathrm{CP}$ level, protein quality and its digestibility as a result of urea or urea plus fungal treatments (Salman et al., 2011). Also, Bassuny et al. (2003b). Aziz et al. (2008) found that urea treatment and biological treatment ( $T$. viride and Saccharomyces cerevisiae) increased both TDN and DCP compared to untreated group.

\section{Nitrogen balance:}

Nitrogen intake, $\mathrm{N}$-excreted and $\mathrm{N}$-balance by sheep fed different experimental rations are presented in Table (4). Data revealed that different values of nitrogen terms were significantly $(P<0.05)$ affected by chemical or biological treatments. $\mathrm{N}$-intake values were higher for sheep fed ration 
containing treated PTBP compared with control (untreated PTBP). The highest value of $\mathrm{NI}$ was observed with R4 followed by $\mathrm{R} 5$ and no significant differences were noticed among R1, R2 and R3. All sheep were in a positive nitrogen balance (NB), however; biological treatments (R2, R3 and R4) had higher $(P<0.05)$ values of $\mathrm{NB} / \mathrm{NI}$ and $\mathrm{NB} / \mathrm{NA} \%$ followed by urea treatment compared with the control one. So, better $\mathrm{N}$-utilization was achieved from treated rations. These findings are in agreement with those obtained by ElAshry et al.(1997); Khorshed (2000); Aziz et al.(2008); Farghaly (2009) and Salman et al.(2011), who reported that animals (sheep\& goats) fed ration contained biologically (fungi, yeast, bacteria and combined of them) treated crop residues (cotton stalks, wheat straw and sugarcane bagasse) had higher positive $\mathrm{N}$-balance. Also, Fayed et al. (2009) reported that feeding biological $(T$. viride $+S$. cerevisi) and urea treatment of pruning olive trees by-products had higher $\mathrm{N}$-balance value than untreated one.

Table (4): Nitrogen utilization $(\mathrm{g} / \mathrm{h} / \mathrm{d})$ by sheep fed experimental rations.

\begin{tabular}{|c|c|c|c|c|c|c|}
\hline \multirow{2}{*}{ Item } & \multicolumn{5}{|c|}{ Experimental rations } & \multirow{2}{*}{$\pm \mathrm{SE}$} \\
\hline & R1 & R2 & R3 & R4 & R5 & \\
\hline \multirow{3}{*}{$\begin{array}{l}\text { Nitrogen intake }(\mathrm{NI}), \mathrm{g} / \mathrm{h} / \mathrm{d} \\
\text { Fecal nitrogen, } \mathrm{g} / \mathrm{h} / \mathrm{d} \\
\text { Urinary nitrogen, } \mathrm{g} / \mathrm{h} / \mathrm{d}\end{array}$} & $10.90^{c}$ & $11.19^{b c}$ & $11.55^{\mathrm{bc}}$ & $13.48^{\mathrm{a}}$ & $12.82^{\mathrm{ab}}$ & 0.528 \\
\hline & $5.21^{\text {ab }}$ & $4.22^{c}$ & $4.42^{\mathrm{bc}}$ & $4.81^{\mathrm{abc}}$ & $5.49^{\mathrm{a}}$ & 0.279 \\
\hline & 2.69 & 2.38 & 2.22 & 2.50 & 2.71 & 0.233 \\
\hline \multirow{4}{*}{$\begin{array}{l}\mathrm{N} \text { absorbed (NA), g/h/d } \\
\mathrm{N} \text { balance (NB), g/h/d } \\
\text { NB/NI, \% } \\
\text { NB/NA, \% }\end{array}$} & $5.69^{c}$ & $6.97^{\mathrm{b}}$ & $7.13^{b}$ & $8.67^{a}$ & $7.33^{b}$ & 0.300 \\
\hline & $3.00^{\mathrm{C}}$ & $4.59^{b}$ & $4.91^{\mathrm{ab}}$ & $6.17^{\mathrm{a}}$ & $4.62^{b}$ & 0.444 \\
\hline & $27.52^{\mathrm{C}}$ & $41.02^{\mathrm{ab}}$ & $42.51^{\mathrm{ab}}$ & $45.77^{\mathrm{a}}$ & $36.04^{b}$ & 2.748 \\
\hline & $52.72^{\mathrm{C}}$ & $65.85^{\mathrm{ab}}$ & $68.86^{\mathrm{ab}}$ & $71.16^{a}$ & $63.034^{b}$ & 4.482 \\
\hline
\end{tabular}
$(\mathrm{P}<0.05)$ different.

It seems that biological treatments improved nitrogen balance as a result of less nitrogen excretion. The highest nitrogen balance by feeding urea treatment may be due to the improvement in the CP digestibility and higher utilization of urea nitrogen by sheep (Fayed et al, 2009). On the other hand, biological treatment improved chemical structure, chemical composition (El-Ashry et al., 2001 and Fayed et al., 2009), digestibility, feeding value and $\mathrm{N}$ - balance of treated wastes (Hassan et al., 2005 and Hamza et al., 2006). Walli et al. (1988) observed that the $\mathrm{N}$ intake, its digestion and retention by cross-bred calves fed fungal treated wheat straw was higher than those fed urea treated wheat straw.

\section{Rumen liquor parameters:}

Rumen fluid parameters are shown in Table (4). No significant $(\mathrm{P}>0.05)$ differences were found for ruminal $\mathrm{pH}$ values among experimental groups at different times. However, concentrations of $\mathrm{NH}_{3}-\mathrm{N}$ were significantly $(\mathrm{P}<0.05)$ higher for rams fed rations contained either urea or biologically treated PTBP than the control ration (untreated PTBP) at 3 and 6 hr. post-feeding. The highest values of $\mathrm{NH}_{3}-\mathrm{N}$ were observed with $\mathrm{R} 5$ and R4. The present results are supported by those of Abo-Eid et al. (2007) who reported that ruminal ammonia was significantly $(P<0.05)$ higher for rams fed rations containing biologically ( $T$. reesei) treated roughage (rice straw, corn stalks, olive pulp and date seeds) than those fed untreated ration. Ammonia reached the maximum concentrations at $3 \mathrm{hr}$. post-feeding for all treatments 
and the lowest values was at zero time. Also, Bassuny et al. (2003b) and Fayed et al. (2009) found that rams fed ration contained urea treated roughage had the highest $\mathrm{NH}_{3}-\mathrm{N}$ concentration followed by those fed ration contained biologically treated roughage.

The increase of ammonia nitrogen by urea treatment may be due to the high NPN content which is easily converted to $\mathrm{NH}_{3}-\mathrm{N}$ during fermentation. However, the increase in $\mathrm{NH}_{3}-\mathrm{N}$ with biological treatment could be a result of breakdown of protein and other nitrogenous compound to $\mathrm{NH}_{3}-\mathrm{N}$ (Fayed et al., 2009).

Table (5): Rumen liquor parameters for animals fed the experimental rations.

\begin{tabular}{|c|c|c|c|c|c|c|c|}
\hline \multirow[b]{2}{*}{ Item } & \multirow{2}{*}{$\begin{array}{l}\text { Time } \\
\text { (hrs.) }\end{array}$} & \multicolumn{5}{|c|}{ Experimental ration } & \multirow{2}{*}{$\pm \mathrm{SE}$} \\
\hline & & R1 & R2 & R3 & R4 & R5 & \\
\hline \multirow{3}{*}{$\mathrm{pH}$} & 0 & 6.61 & 6.82 & 6.69 & 6.76 & 6.70 & 0.062 \\
\hline & 3 & 6.22 & 6.38 & 6.25 & 6.40 & 6.47 & 0.016 \\
\hline & 6 & 6.58 & 6.77 & 6.63 & 6.71 & 6.56 & 0.125 \\
\hline \multirow{3}{*}{$\mathrm{NH}_{3}-\mathrm{N}(\mathrm{mg} / 100 \mathrm{ml})$} & 0 & 15.79 & 17.37 & 15.97 & 17.93 & 17.65 & 1.472 \\
\hline & 3 & $20.55^{\mathrm{C}}$ & $28.29^{b}$ & $26 . .17^{\mathrm{bc}}$ & $33.89^{\mathrm{a}}$ & $34.99^{\mathrm{a}}$ & 0.752 \\
\hline & 6 & $18.12^{b}$ & $20.64^{a b}$ & $19.61^{\mathrm{D}}$ & $21.48^{\text {ab }}$ & $24.75^{a}$ & 1.869 \\
\hline \multirow{3}{*}{ TVFA's(meq./100ml } & 0 & $8.33^{d}$ & $10.13^{b}$ & $10.49^{b}$ & $11.81^{\mathrm{a}}$ & $9.22^{c}$ & 0.248 \\
\hline & 3 & $9.89^{d}$ & $12.96^{\mathrm{b}}$ & $13.59^{b}$ & $15.15^{\mathrm{a}}$ & $11.54^{\mathrm{C}}$ & 0.339 \\
\hline & 6 & $7.57^{\mathrm{C}}$ & $11.21^{\mathrm{b}}$ & $11.12^{b}$ & $13.38^{\mathrm{a}}$ & $8.01^{\mathrm{C}}$ & 0.664 \\
\hline
\end{tabular}
$(P<0.05)$ different.

Data in Table (4) indicated that TVFA's concentrations were significantly increased $(\mathrm{P}<0.05)$ by feeding rations contained urea or biologically treated PTBP compared with the control (R1). On the other hand, biological groups had higher TVFA's concentration than urea group; especially R4 which had the highest concentration of TVFA's. Generally, concentrations of TVFA's reached to the highest values at $3 \mathrm{hr}$. post-feeding then declined at $6 \mathrm{hr}$. post-feeding and the lowest values were noticed at zero time. These results are in agreement with those obtained by Bassuny. (2003b) who recorded that the highest concentration of TVFA's was observed with rams fed ration contained biological treated roughages followed by those received urea treated roughage compared to the control. Also, El-Sayed et al. (2002) and Mahrous and Khorshed (2012) reported that animals (sheep \& goats) fed rations contained biologically ( $T$. viride, $S$. cervisiae, $T$. reesei, $P$. funculusms and $T$. reesei $+P$. funculusms) treated roughage (corn stalk and sugarcane bagasse) had higher $(P<0.05)$ concentrations of TVFA's than those fed control ration which indicated better fermentation in the rumen.

Kumar et al. (1997) and Bassuny et al. (2003b) attributed the increase in concentration of TVFA's as a result of using biological treatment to the high fiber breakdown. Also, Doane et al. (1997) reported that TVFA's production was correlated with NDF disappearance and higher concentration of TVFA's in the rumen of biological treatment may be a result of altered rumen microbial populations and microbial activity. However, Allam et al. 
(2006b) reported that TVFA's concentrations in rumen is governed by several factors, such as DM digestibility, rate of absorption, rumen $\mathrm{pH}$, transportation of the digesta from rumen to other parts of digestive tract and the microbial population in the rumen and their activity.

\section{Blood parameters:}

Blood plasma parameters for rams fed experimental rations are illustrated in Table (6). The present data showed insignificant $(P<0.05)$ differences among the different experimental rations for blood plasma total protein, albumin, globulin, urea, GOT and GPT. However, blood plasma total protein and urea were insignificantly increased for rams fed urea or fungi treated PTBP compared to those fed control ration (untreated PTBP). These insignificant increases of blood plasma total protein and urea may be due to the increase of $\mathrm{N}$-intake and its higher digestibility which reflected on ruminal NH3-N and finally the blood plasma constituents. These results are in agreement with those obtained by Deraz and Ismail (2001) and Mahrous et al. (2011) who found that no significant differences were noticed in blood plasma parameters among all groups fed untreated or fungal treated crop residues and the values were within the normal range. Also, Hassan et al. (2005) found no significant differences among groups concerning all blood constituents for dairy cows fed untreated or biologically treated banana wastes. On the other hand, the present results disagree with those obtained by Bassuny et al. (2003b) who found that blood components were significantly affected $(\mathrm{P}<0.05)$ by treatments. The higher values of total protein, albumin, urea, GOT and GPT were recorded with urea + fungi treatment followed by urea treatment compared to untreated group.

Table (6): Blood plasma parameters for rams fed experimental rations.

\begin{tabular}{|c|c|c|c|c|c|c|}
\hline \multirow{2}{*}{ Item } & \multicolumn{5}{|c|}{ Experimental ration } & \multirow{2}{*}{ $\pm S E$} \\
\hline & R1 & R2 & R3 & R4 & R5 & \\
\hline Urea $(\mathrm{mg} / 100 \mathrm{ml})$ & 26.15 & 28.09 & 27.83 & 28.06 & 28.74 & 3.125 \\
\hline $\begin{array}{l}\text { Total protein } \\
(\mathrm{g} / 100 \mathrm{ml})\end{array}$ & 7.65 & 7.70 & 7.70 & 7.74 & 7.71 & 0.392 \\
\hline Albumin $(\mathrm{g} / 100 \mathrm{ml})$ & 3.86 & 3.87 & 3.85 & 3.96 & 3.99 & 0.105 \\
\hline Globulin (g/100ml) & 3.79 & 3.84 & 3.86 & 3.77 & 3.73 & 0.317 \\
\hline GOT $(\mathrm{U} / \mathrm{L})$ & 21.15 & 21.83 & 21.70 & 20.75 & 21.52 & 0.858 \\
\hline GPT $(\mathrm{U} / \mathrm{L})$ & 33.15 & 33.87 & 34.01 & 34.09 & 34.89 & 2.192 \\
\hline
\end{tabular}

The present values of blood plasma constituents for all experimental groups were within the normal range for healthy sheep reported by Cornelius (1970) and Merck (1991). It is of interest to recognize that either urea or fungal treatments had no adverse effect on liver function and lambs were found to be healthy under such feeding program.

\section{Growth performance and economic efficiency:}

Data in Table (7) indicated that although the initial body weight of lambs of all groups were similar yet the final body weight, total gain and daily gain were significantly $(P<0.05)$ higher for lambs fed rations contained fungal treated PTBP than those fed untreated PTBP (control). However, lambs fed urea treated PTBP had insignificant higher final body weight, total gain and daily gain compared with control. These results are in agreement with Shaker 
et al. (2011) who reported that lambs fed barley straw treated with fungi had higher $(P<0.05)$ final body weight and daily gain $\left(39.76 \mathrm{~kg}\right.$ and $\left.228 \mathrm{~g} \mathrm{~d}^{-1}\right)$ as compared with those fed untreated straw $\left(34.8 \mathrm{~kg}\right.$ and $\left.154 \mathrm{~g} \mathrm{~d}^{-1}\right)$. While, lambs fed urea treated barley straw showed insignificant difference $(35.0 \mathrm{~kg}$ and $166 \mathrm{~g} \mathrm{~d}^{-1}$ ). Also, Fayed et al. (2012) showed that average daily gain for lambs fed ration contained potato veins treated with fungi $(T$. reesei) was higher $(P<0.05)$ than those fed control ration (untreated potato veins).

Fayed et al. (2012) reported that the effect of fungal treatment on increasing final body weight and daily gain was mainly due to the improving in digestibility, metabolizable energy content and palatability. Also, Belewu and Popoola (2007) recorded that significant $(P<0.05)$ higher values of weight gain for lambs fed fungal treated based diet could be due to higher feed intake and the sawdust was predigested by the fungus before its inclusion in the diet. Moreover, Abdel-Azim et al. (2011) claimed that fungal (T. viride) treated rice straw and corn stalks improved their feeding values resulting in higher intake, $\mathrm{N}$-balance and growth rate in cross-bred lambs.

Average dry matter intake (DMI) was higher for lambs fed R4 (PTBP treated with $T$. reesei+T. viride) followed by R3, R2 and R5 compared to R1 (Table 7). It was observed that DMI from the roughage was increased following the treatment of either with the fungus or urea. Meantime, more roughage intake was seen with the fungi treatment roughage than from those treated with urea. These results are in agreement with those obtained by Aziz et al. (2008) and Shaker et al. (2011) who reported that DMl of lambs fed urea and biologically (Phanerocheate chrysosporium, T. viride and Pleurotus ostreatus) treated roughage (olive tree by product and barley straw) was significantly increased as compared with the control. Also, Gado (1999) and Belewu and Popoola $(2007)$ reported that DMI was higher $(P<0.05)$ for lambs fed fungal ( $T$. reesei and Rhizopus oligosporus) treated roughage (rice straw, bagasse and sawdust) than those fed control. This increment of DMI may be due to the increase of the rate of digestion (Gado, 1999 and Shaker et al., 2011) and/or to improve palatability of biologically treated roughage (Belewu and Popoola, 2007 and Soliman et al., 2009).

Feed conversion expressed as $\mathrm{kg} \mathrm{DM} / \mathrm{kg}$ gain tended to be higher for lambs fed biologically treated PTBP than those fed control diet (Table 7). Urea treatment was slightly improved feed conversion compared to control (7.05 vs. $7.18 \mathrm{~kg} \mathrm{DM} / \mathrm{kg}$ gain). The present data are in agreement with those recorded by Fouad et al. (1998) and Allam et al. (2006 a) who found that feed conversion of animal fed biologically treated roughage showed the most efficient groups followed by those fed chemically treated roughage. Also, Mahrous and Khorshed (2012) reported that fungal treated rice straw groups ( $P$. funiculusms, $T$. reesei and combination of two fungi) recorded better feed conversion (g DM/g gain) than control group. Feeding of fungus treated diet to ruminant animals improve feed efficiency because of direct incorporation of fatty acids and microbial protein (Meszkiewics et al. 2004). Belewu and Popoola (2007) reported that improving feed efficiency of fungal treated sawdust group could be a result of direct improvement in the nutrient content of sawdust. 
Table (7): Effect of experimental rations on growth performance and economic efficiency of lambs (120 days).

\begin{tabular}{|c|c|c|c|c|c|c|}
\hline \multirow{2}{*}{ Item } & \multicolumn{5}{|c|}{ Experimental rations } & \multirow{2}{*}{ \pm SE } \\
\hline & R1 & R2 & R3 & R4 & R5 & \\
\hline $\begin{array}{l}\text { Initial live body weight } \\
\text { (I.B.W), Kg }\end{array}$ & 18.2 & 18.4 & 18.4 & 18.4 & 18.2 & 1.073 \\
\hline $\begin{array}{l}\text { Final live body weight } \\
\text { (F.B.W), Kg }\end{array}$ & $31.8^{b}$ & $36.4^{\mathrm{a}}$ & $37.8^{\mathrm{a}}$ & $38.6^{a}$ & $34.6^{\mathrm{ab}}$ & 1.452 \\
\hline Total body gain, $\mathrm{Kg}$ & $13.6^{\mathrm{C}}$ & $18.0^{\mathrm{ab}}$ & $19.4^{\text {ab }}$ & $20.2^{a}$ & $16.4^{\mathrm{DC}}$ & 1.171 \\
\hline Daily gain, $\mathrm{g}$ & $115^{\mathrm{C}}$ & $150^{\mathrm{ab}}$ & $162^{\mathrm{ab}}$ & $168^{\mathrm{a}}$ & $137^{\mathrm{bc}}$ & 9.708 \\
\hline \multicolumn{7}{|l|}{ Intake: } \\
\hline Concentrate (DMI), g & 751 & 773 & 817 & 844 & 774 & \\
\hline PGTB (DMI), g & 175 & 198 & 215 & 224 & 189 & \\
\hline Total DMI, g & 826 & 971 & 1032 & 1068 & 963 & \\
\hline $\begin{array}{l}\text { Feed conversion(DMI } \\
\mathrm{Kg} / \mathrm{Kg} \text { gain) }\end{array}$ & 7.18 & $6 . .47$ & 6.38 & 6.34 & 7.05 & \\
\hline \multicolumn{7}{|l|}{ Economic Efficiency } \\
\hline Price of daily gain, LE & 4.03 & 5.25 & 5.66 & 5.89 & 4.78 & \\
\hline $\begin{array}{l}\text { Concentrate feed } \\
\text { mixture, LE }\end{array}$ & 1.802 & 1.855 & 1.961 & 2.026 & 1.857 & \\
\hline $\begin{array}{l}\text { Pruning grape trees by- } \\
\text { product, LE }\end{array}$ & 0.044 & 0.050 & 0.054 & 0.056 & 0.047 & \\
\hline Daily feed cost, LE & 1.846 & 1.905 & 2.015 & 2.082 & 1.904 & \\
\hline Feed cost/kg gain, LE & 16.05 & 12.70 & 12.46 & 13.37 & 13.94 & \\
\hline Daily profit, LE & 2.18 & 3.35 & 3.64 & 3.81 & 2.89 & \\
\hline Relative feed cost, \%* & 100 & 79.10 & 77.62 & 77.03 & 86.82 & \\
\hline $\begin{array}{l}\text { Relative daily profit, } \\
\%^{* *}\end{array}$ & 100 & 154 & 167 & 175 & 132 & \\
\hline
\end{tabular}
different.

Price of 1 ton CFM= 2400 LE Price of 1 ton un-treated grape pruning tree by product $=\mathbf{2 5 0}$ LE. Price of 1 ton treated pruning grape trees by-product $=295 \mathrm{LE}$. Market price of $1 \mathrm{~kg}$ live body weight in (2014) = 35 LE. *Relative feed cost, \%=Feed cost, LE/kg gain (R2, R3, $\mathbf{R} 4$ or $\mathbf{R 5}) / \mathbf{R} 1 .{ }^{* *}$ Relative daily profit, \% =Daily profit LE (R2, R3, R4 orR5)/R1.

Regarding to economic efficiency, results showed that R4 had the lowest relative cost (\%) and feed cost LE/kg gain followed by R3, R2 and R5 compared with control. Daily profit, LE and relative profit, (\%) were improved by feeding rations contained treated PTBP and the best values were observed with R4 followed by R3, R2 and R5 in comparison with the control one (R1).These results are in agreement with Deraz (1996) and Ibrahim (2001) who reported that chemical and biological treatments of rice straw and corn stalks decreased the cost of feeds used to produce $1 \mathrm{~kg}$ of live body weight gain. Also, Soliman et al. (2009) and Abdel-Azeem et al. (2011) recorded that feed cost per $\mathrm{kg}$ gain and economic efficiency were better with animals (calves and sheep) fed rations containing fungal (T. hariznoum and $T$. viride) treated roughage (corn stalks and straws of wheat, rice, bean and clover) than untreated ration. 


\section{CONCLUSION}

It could be concluded that incorporation of Fungus treatment of pruning peach trees by-products in lambs rations improves digestibility, nutritive value and increasing the performance of growing lambs meanwhile, solving the problem of environmental pollution and treatment with a combined of the two fungi (R4) showed the best results.

\section{REFERENCES}

A.O.A.C. (1995). Official Methods of Analysis (16th) Edt. Association of Official Analytical Chemists, Washington, D.C., USA.

Abd El-Ghani, A. A.; F. M. R. El-Feel; E. Shehata and E. Ibrahim (1999). Influence of feeding banana plant wastes treated by urea or sodium hydroxide on digestibility, rumen fermentation characteristics and performance of growing sheep. J. Agric. Sci. Mansoura Univ., 24:107.

Abdel-Azim, N. Safa; Ahmed, A. Mona; F. Abo-Donia and H. Soliman. (2011). Evaluation of fungal treatment of some agricultural residues. Egyptian J. of Sheep and Goat Sci., 6(1): 1- 13.

Abdel-Malik, W. H.; A. M. Abdel-Gawad; I. M. E. Shakweer and G. M. Khalafalla (2003). Improving banana wastes using chemical and biological treatments. Egyptian J. Nutrition and Feeds, 6(Special Issue): 1039.

Abo-Eid, H.A.; M.A El-Ashry.; M.M. Korshid and M.F. El-Sayed (2007). Effect of biological treatments of some crop residues on their nutritive values: 1- Effect of biological treatments on recovery rate, chemical composition and in situ disappearance. Egyptian J. Nutrition and feeds, 10(2): Special Issue: 493-508.

Abou-Akkada, A. R. and H. E. Osman (1967). Studies on the utilization of non-protein nitrogen in Egypt. J. Agric. Sci., 169: 25-33.

Akinfemi, A. and M. K. Ladipo (2013). Biocoversion of Danielliaoliveri tree sawdust into ruminant feed. Pat June, 9(1): 105.

Allam, M. Sabbah; Hoda, M. El- Hosseiny; M. Fadel; H. M. El- Banna and A. R. Refai (2006a). Nutrients utilization and growth performance of lambs fed rations containing corn stover treated chemically and biologically. J. Agric. Sci. Mansoura Univ., 31(4):1993-2007.

Allam, S. M.; T. M. Al-bedawi; Hanaa H. El-Amary and Shereen H. Mohamed (2006b). Improving sugar beet pulp through biological treatment and its use in sheep ration. Egyptian J. Nutrition and Feeds, 6(2): 235- 247.

Armstrong, W. D. and C. W. Carr (1964). Physiological. Chemistry $3^{\text {rd }}$ ed. pp., 75 Burges Publishing CO. Minneapolis, Minnesota, USA.

Aziz, A. Hend; M. A. El-ashry; Fayed M. Afaf, M. M. Khorshed and Ab.N.Khattab (2008). Using of olive trees by-products treated biologically or chemically for sheep feeding in Sinai. Egyptian J. Nutr.and Feeds, 11(2):309-328. 
Bassuny, S.M.; A.A. Abdel-Aziz; M. F. El-Sayis and M.A. Aabdulla (2003b). Fibrous crop by-products as feed. 2. Effect of chemical and biochemical treatments on feed intake, nutritive values and some ruminal and blood constituents. Egyptian J. Nutrition and Feeds, 6 (Special Issue): 901-912.

Bassuny, S.M.; A.A. Abdel-Aziz; M.F. El-Sayis; M.N.Omar; H.M. Abdel-Fatah and M.A. Aabdulla (2003a). Fibrous crop by-products as feed. 1. Effect of biological, chemical and biochemical treatments, sterilization possesses and incubation period on chemical composition and in vitro digestibility of corn cobs and sugar cane bagasse. Egyptian J. Nutrition and Feeds, 6 (Special Issue): 891-900.

Belewu, M. A. (2006). Conversation of Mansonia Tree sawdust and cotton plant by product into feed by white rot fungus. Afr. J. Biotechnol., 5(19): 1763- 1764.

Belewu, M. A.and K. Y. Belewu (2005). Evaluation of feeding graded revels of Aspergillus treated rice husk on milk yield and composition of goat. Bull. Pure Appl. Sci., 24(2): 29- 35.

Belewu, M. A. and M. A. Popoola (2007). Performance characteristics of West African dwarf goat fed rhizopus treated sawdust. Scientific Research and Essay, 2 (9):496.

Bilandzija, N.; N. Voca; T. Kicka; A. Matin and V. Junsic (2012). Energy potential of fruit tree pruned biomass in Croatia. Spanish Journal of Agricultural Research, 10(2): 292- 298.

Chandra, S.; M. R. Reddy and G. V. N. Reddy (1991). Effect of fungal treatment of paddy straw on nutrient utilization in complete diet for sheep. Indian J. of Anim. Sci., 61(12): 1330.

Conway, E.F. and E. O'Mally (1957). Micro diffusion methods. Ammonia and urea using buffered absorbents. Biochem. J., 36: 655.

Cornelius, C.E. (1970). Clinical Biochemistry of Domestic Animals. Kanek and Cornelius, New York Acad.

Dass, R. S.; U. R. Mehra and A. K. Verma (2000). Nitrogen fixation and in situ dry matter and fiber constituent disappearance of wheat straw treated with urea and boric acid in Murrah buffaloes. Asian Australian Journal of Animal Sciences, 13: 1113.

Deraz, T. A. (1996). The production of microbial protein from some agricultural wastes and its utilization in ruminant. Ph. D. Thesis, Fac. of Agric. Ain Shams Univ.

Deraz, T. A. and H. Ismail (2001). Cotton stalks treated with white- rot fungus for feeding sheep. Egyptian J. Nutrition and Feeds, 4 (Special Issue): 423.

Doane, P. H.; P. Schofield and A. N. Pell (1997). Neutral detergent fiber disappearance and gas volatile fatty acid production during the in vitro fermentation of six forages. J. Anim. Sci., 75: 3342-3352.

Doumas, B. T.; W. A. Wastson and H. G. Biggs (1971). Albumin standards and the measurement of serum albumin with bromocresol green. Clin. Chem. Acta., 31:87-90.

Duncan, D. B. (1955). Multiple ranges and multiple F -test. Biometrics, 11: 1. 
Egyptian Ministry of Agriculture. (2012). Bulletin of the Agricultural Statistics. Part (2) Summer \&Nilicrops.211

El-Ashry, M. A.; M. F. Ahmed; S. A. El-Saadany; M. E. S. Youssef; I. A. Gommaa and T. A. A. Deraz (1997). Effect of mechanical vs. mechanochemical or mechano-biochemical treatments of crop residues on their use in ruminant ration: Digestibility, nitrogen balance and some blood and rumen liquor parameters of sheep. Egyptian J. Nutr. and Feeds, 1 ( Special Issue):173-186

El-Ashry, M.A.; H.M. El-Sayed; M. Fadel; H. M. Metwally and M. M. Khorshed (2002). Effect of chemical and biological treatments of some crop residues on their nutritive values. 2- Effect of biological treatments on chemical composition and in-vitro and disappearance. Egyptian J. Nutrition and Feeds, 5 (2): 43- 54.

El-Ashry, M.A.; A.M. Kholif; M. Fadel; H.A. El-Alamy; H.M. El-Sayed and S.M. Kolif (2001). Biological treatments of banana wastes for lactating goats feeding.Prof. $8^{\text {th }}$ Conf. Anim. Nutrition. Sharm El-Sheikh, Egypt.

El-Kady, R. I.; I. M. Awadalla; M. I. Mohamd; M. Fadel and H. H. Abd ElRahman (2006). Effect of exogenous enzymes on the growth performance and digestibility of growing buffalo calves. International J. of Agric and Biology, 8: 354.

El-Sayed, H. M.; M. A. El-Ashry; H. M. Metwaly; M. Fadel and M. M. Khorshed (2002). Effect of chemical and biological treatments of some crop residues on their nutritive value. 3-Digestion coefficient, rumen and blood serum parameters of goat. Egyptian J. Nutr. and Feeds, 5(1): 55-69.

Farghaly, M.S. (2009). Influence of treated some poor quality roughages with urea, lime and molasses on growing Rahmany lambs performance. Egyptian J. Nutr. and Feeds, 12 (2): 279-286.

Fayed, M. Afaf; M. A. El-Ashry and Aziz A. Hend (2009). Effect of feeding olive tree pruning by-products on sheep performance in Sinai. World J. Agric. Sci., 5(4): 436-445.

Fayed, M. A. Amal; M. H. M. Yacout; A. A. Mahrous; A. A. Hassan and Zedan $\mathrm{H}$. Afaf (2012). Improving of nutritive value of potato veins by biological treatments and its effect on small ruminants' production performance. Egyptian J. Nutr. and Feeds, 15 (1):261-271.

Fouad, R. T.; T. A. Deraz; and S. A. Attiat-Ismaeil (1998). Biological versus urea treatment of roughages for sheep. J. Agric. Sci. Mansoura Univ., 23 (1): 103-116.

Gado, H. (1999). The effects of treating rice straw or bagasse with steam and Trichoderma Reesi on chemical composition and nutritive value for Baladi goats. Egyptian J. Nutrition and Feeds, 2(1): 9-16.

Gado, H. H.; H. M. Metwally; H. S. Soliman and Etab, R. I. Abd El-Galil (2007). Effect of biological treatments by cellulolytic bacteria on chemical composition and cell wall constituents of some roughage. Egyptian J. Nutrition and Feeds, 10(1):123.

Hammouda, H.I. A. (1996). Biochemical studies on some agricultural residues. Ph. D. Thesis. Fac. of Agric. Ain-Shms Univ. Cairo Egypt. 
Hamza, Akila S.; T. F. Mohammadi; A. A. H. El-Tahan and M. M. ElShennawy (2006). Effect of combining two biological treatments on chemical composition, digestibility and feeding values of cotton stalks fed to sheep. Egyptian J. of Sheep, Goat and Desert Animals Sci., 1: 187-197.

Hart, F. J. and M. Wanapat (1992). Physiology of digestion of urea treated rice straw in swamp buffalo. Asian Australian Journal of Animal Sciences, 5: 617.

Hassan, A. A.; M. H. M. Yacout; M. K. K. Mohsen; M. I. Bassiouni and M. Abd-El-All (2005). Banana wastes (Musa acuminate $L$ ) silage treated biologically or with urea for dairy cows feeding. Egyptian J. Nutr. and Feeds, 8 (Special Issue):49.

Ibrahim, M. N.; S. Tamminga and G. Zemmelink (1989). Effect of urea treatment on rumen degradation characteristics of rice straws. Anim. Feed Sci. and Technol., 24: 83.

Ibrahim, M.E. (2001). Effect of mechanical, chemical and biological treatments of roughage on ruminal activity. Ph. D. Thesis, Fac. of Agric., Cairo Univ., Egypt.

Jakson, M. G. (1977). The alkali treatment of straws- A review. Animal Feed Sci. and Technol., 2:105.

Kamel, H. E. M. Sekine, J., Suga, T. and Morita, Z. (1995). The effect of frozen-rethawing technique on detaching firmly associated bacteria from in situ hay residues. Can. J. of Anim. Sci., 75:481-483

Khan, M. J.; J. R. Scaif and F. D. Hovell (1999). The effect of different sources of urease enzyme on nutritive value of wheat straw treated with urea as source of ammonia. Asian Australian Journal of Animal Sciences, 12: 1063.

Khorshed, M. M. A. (2000). Different treatments for improving nutritional quality of some crop residues used in ruminant nutrition. Ph. D., Fac. of Agric., Ain Shams Univ.

Kumar, U.; V. K. Sareen and S. Singh (1997). Effect of yeast culture supplement on ruminal population and metabolism in buffalo calves fed high roughage diet. J. Sci. Food and Agric., 73:231.

Mahrous, A. A. (2005). Effect of fungus treatments of cotton stalk on sheep performance. Egyptian J. Nutrition and Feeds, 8 (2) Special Issue: 529.

Mahrous A. A. and M. M. Khorshed (2012). Improving the nutritive value of rice straw by fungal treatments for feeding sheep. Egyptian J. Nutr. and Feeds, 15 (2):247-254.

Mahrous A. A.; E. H. El-Shafie and T. M. M. Abdel- Khalek (2011). Performance of Growing lambs fed fungus treated sugarcane bagasse. Egyptian J. of Sheep and Goat Sci., 6(1): 27-35.

Mahrous A. A.; A. Khorshed and Y. H. Hafez (2010). Effect of biological treatment on improvement of sugarcane bagasse nutritive value and its effect on productive of lactating buffaloes. Egyptian J. Nutrition and Feeds, 13 (2): 205-217.

McDonald, P. (1981). Biochemistry of Silage, PP 226 Chichester. John Wiley \& Sons. 
Mehrez, A. Z. and E. R. Ørskov (1977). A study of the artificial fiber bag technique for determining the digestibility of feed in the rumen. J. Agric. Sci. (Camb.) 88:645

Merck (1991).The Merck Veterinary Manual. Seven Edition. 1991

Meszkiewics H.; M. Bizukoje; A. Rozwandewicz and S. Bielecki (2004). Physiological properties and enzymatic activities of Rhizopus oligosporus in solid state fermentations. Elect.J. Polish Agric. Uni. (Biotechnology series), 7: 1-6.

Nandra, K. S.; A. Hendry and R. C. Cobos (1983). A study of voluntary intake and digestibility of roughages in relation to their degradation characteristic and retention time in the rumen. Anim. Feed Sci. and Technol., 43: 227.

Nasehi, M.; N. M. Torbatinegad; S. Zerehdaran and A. R. Safaei (2014). Effect of (Pleurotus Florida) fungi on chemical composition and rumen degradability of wheat and barley sraw. Indian J. of Appl. Anim. Sci., 4 (2): 257-261.

NRC. (1985). Nutrient Requirements of Domestic Animals Nutrient Requirements of Sheep $5^{\text {th }}$ Ed. National Academy of sciences- National Research Council, Washington D. C. , USA.

Ørskov, E. R. and I. MacDonald (1979). The estimation of protein degradability in the rumen from incubation measurements weighted according to rate of passage. J. Aric. Sci., 92, 499- 503.

Ørskov, E. R. and M. Ryle (1990). Energy Nutrition in Ruminants. P. 133-143. Elsevier Science. Ltd., Essex, UK.

Reitman, S. and S. Frankel (1957). Colorimetric determination of GPT activity according to the Reitman and Frankel method. Am. J. Clin. Path., 28.Res38:191-195.

S.A.S. (2001). SAS user's guide: Statistics, 6th Ed. Cary, N.C.: SAS Institute, Inc. Cary. NC. USA.

Salman M. Fatma; R. Salama; A. E. Khattab; S.M. Soliman and Y. A. ElNomeary (2011). Chemical biological and biochemical treatments to improve the nutritive values of sugarcane bagasse (SCB): 1- Chemical composition scanning electron microscopy, in vitro evaluation nutrients, digestibility and nitrogen utilization of untreated or treated SCB. Life Science J., 8(4): 351-363.

Sancholle, M. and DM. Losel (1995). Lipids in fungal biotechnology.In : The Mycote II. Genetics and Biotechnology Published by Berlin: Spring Verlag. Pp. 339- 352.

Shaker A. H.; M. S. Sarwar and M. H. Khasraw (2011). Effect of feeding chemical and microbial treated barley straw on performance and some serum biochemical attributes of Karadi lambs. Ksu. J. Nat. Sci., 14(3):29-38.

Shoukry, M. M.; F. A. Hamissa; M. Sawsan , A. H. El-Refi; H. M. Ali and Z. M. Z. Abdel-Motagally (1985). Nutritive improvement of some low quality roughages for ruminants. 1 . Effect of different microbial and chemical treatments on quality of sugarcane bagasse. Egyptian J. Animal Production, 25:329. 
Siest, G.; J. Henny and F. Schiela (1981). Interpretion des examens de laboratories, PP. 206, Karger Ed

Silva, A. T.and E. R. Ørskov (1998). Fiber degradation in the rumen of animal receiving hay, untreated or ammonia-treated straw. Anim. Feed Sci. and Technol., 19: 227.

Snedecor, W. and W. Cochran (1980). Statistical Methods.lowa State University Press, Ames lowa, seventh edition.

Soliman, A. A. M.; M. S. Lasheen; A. A. Hegazy; M. F. Ahmed and M. G. Zweil (2009). Performance of growing crossbred Friesian calves fed biological treated roughages and concentrate: 1 - feeding value and animal performance. Egyptian J. Nutrition and Feed, 12(1):15-26.

Theander, O. and P. Aman (1984).Anatomical and chemical characteristics. In: Sundstl, F. and Owen, E (eds). Straw and other fibrous by-products as feed. Elsevier Sci. Publishers, Amsterdam. Chapter 4.

Van Soeat, P.J. (1982). Nutritional Ecology of the Ruminat. Books, Inc., Caravels, USA.

Verma, A. K.; P. Singh; R. S. Dass and U. R. Mehra (2006). Impact of feeding urea ammoniated and urea supplemented wheat straw on intake and utilization of nutrients in crossbred cattle. Indian J. of Anim. Sci., 76(6): 406-470.

Villas-Boas, S.G.; E. Esposito and D. A. Mitchell(2002). Microbial conversion of lignocellulosic residues for Production of animal feeds. Journal of Animal Feed Science and Technology, 98, 1-2.

Walli, T. K.; B. N. Gupta; S. N. Rai; K. Singh (1988). Biological treatment of straw $\mathrm{N}$-transactions during fermentation and sequence utilization by ruminants. In: Mahesh, M. S. and Madhu Mohini (2013). Biological treatment of crop residues for ruminant feeding: A review. African J. of Biotchnol., 12(27): 4221-4231.

Zewil, M. G. M. (2005). Evaluation of some treatments for rice straw. M. Sc. Thesis, Fac. of Agric. Al-Azhar univ. Egypt.

Živković, M.; M. Urošević; S. Oljača; M.Oljača, K. Gligorević; I. Zlatanović and R.Koprivical (2013). Aspects of using potential energy products of biomass after pruning fruit and grape plantations in The Republic of Serbia. Agriculture \& Forestry, 59(1):167-182. 
Khir, A. A. et al.

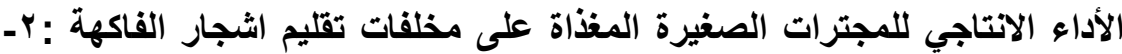

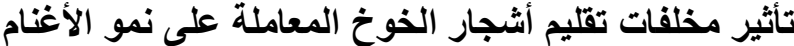

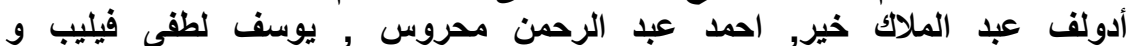 صفاء نادى عبد العظيم معهد بحوث الانتاج الحيوانى- مركز البحوث الزراعية ـ الدقى ـ الجيزة- مصر.}

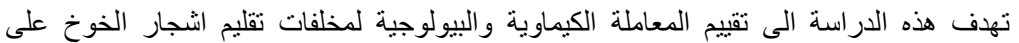
التركيب الكيماوى ومعاملات الهضم والقيمة الغذائية وتاثير التغذية علية عليها على التى الاداء الانتاجي للحملان

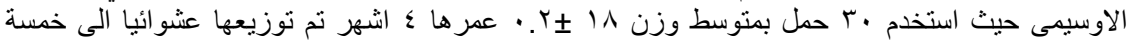

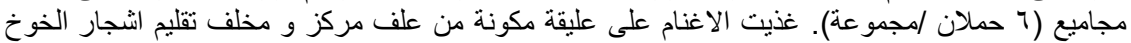

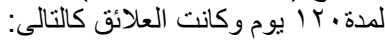

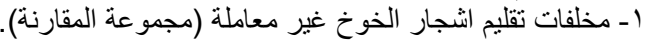

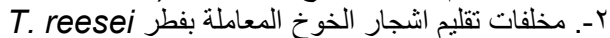

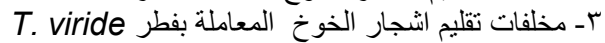

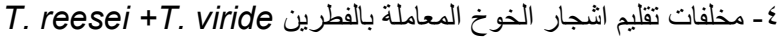

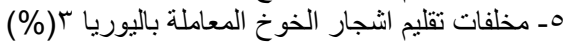

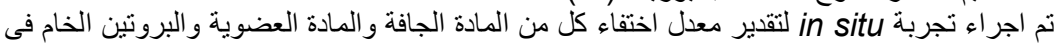

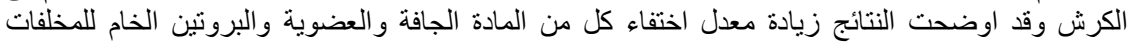

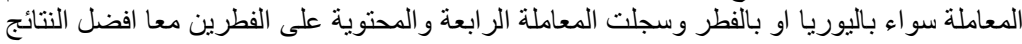

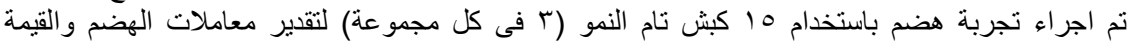

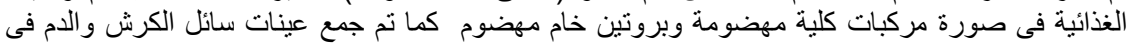

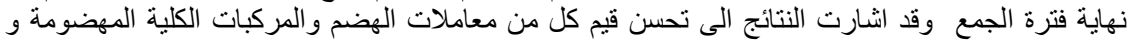

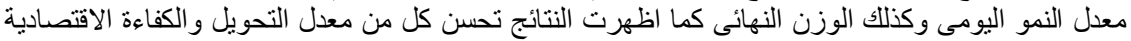

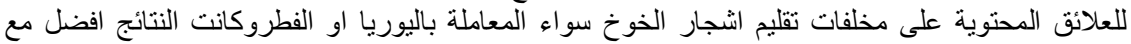

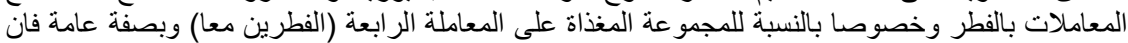

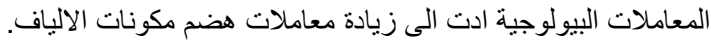

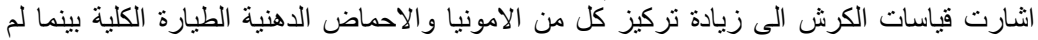

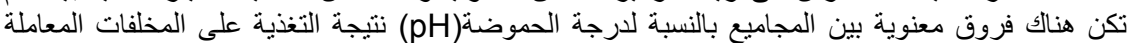

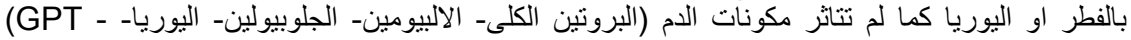

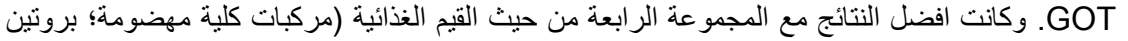

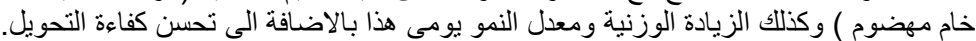

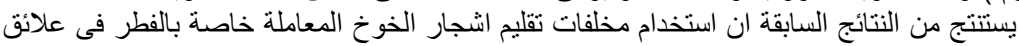

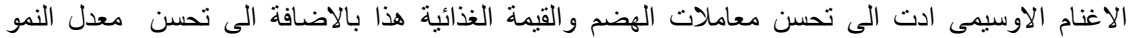

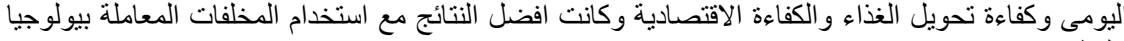

